\title{
Tapping Urban Voids: Transforming Abandoned Urbanscapes into Communal Hubs
}

\author{
Ananya SETHI, Architect, India \\ Ramadass Bama THIRUVENGADAM, Architect \& Urban Designer, India
}

\begin{abstract}
As cities in developing countries across the globe grapple with challenges of extreme densification, satellite towns have sprouted in response as urban offshoots on greenfield sites. These towns excel at providing housing and infrastructure for the affluent, but the livability quotient for other socio-economic groups is questionable. India, home to several such cities, has witnessed meteoric growth and is expected to house the largest urban population in the world by 2050. Gurugram, one of New Delhi's satellite cities, exhibits a dichotomy. It is a seemingly elite urban island for the wealthy, but is sparingly developed in haphazard pockets. It has witnessed private development without the required civic infrastructure, resulting in a city lacking egalitarian urbanscapes. This paper seeks to explore these challenges in collaboration with Better Habitat Foundation, a non-profit that seeks to ameliorate the socio-cultural environment in urban India. Exploring the urban development and regeneration of urban voids, a 50-acre defunct site with four independent markets was selected as the pilot project in Gurugram. Though earmarked for green development, the site lays completely barren, and the condition of the markets is not optimal. The shortcomings presented on site become opportunities to guide the design that would result in the formation of an urban catalyst. This initiative seeks to become a precedent, paving the way for such developments in satellite cities across the globe.
\end{abstract}

\section{Keywords}

Urban Design, Public Spaces, Satellite City, Inclusive Planning, Urban Voids, Urbanization

\section{Introduction}

The proliferation of cities as living entities is resulting in unsustainable urban growth patterns across the globe (World Bank, 2019). While megacities start showing signs of age and decay over time, newer offshoots in the form of satellite cities exhibit heterogeneity in development patterns. Every city houses pockets of underdeveloped urban environments that may be detrimental for the city in the long run (Amirtahmasebi et al., 2016). Such environs reinforce the segregation of income classes through the difference in availability of infrastructure to disparate user groups. Geographical and social segregation of communities in this manner may become a global predicament and a catalyst towards social discontent (Ward, 2018).

Urban renewal, redevelopment and revitalization projects thus become crucial to the success of cities, old and new. They exhibit merit in the form of restoring economic viability while bridging the gap amongst economic classes and instilling a sense of civic ownership and pride (UN Sustainable Development Solutions Network, 2013). 
This paper is an exploration towards the revitalization and transformation of a desolate urban void in Gurugram, India, to ameliorate the urban landscape and subsequently uncover the untapped potential it entails towards the creation of an equitable city. The research presents an overview on the current situation of urbanization in India, the formation of satellite cities with a focus on Gurugram, and the pertinence of public spaces on communities. Case studies exploring similar themes have been analyzed to help guide, direct and propose measures, guidelines and reforms for the activation of defunct urbanscapes.

\subsection{Urbanization in the Indian Context}

The unprecedented and often chaotic urban development witnessed by developing countries presents opportunities for growth and challenges alike. With a high concentration of people and increase in proximity with positive and negative externalities, economic opportunities for the poor swell, but ubiquitous challenges, such as strained resources, limited infrastructure and vulnerability of the population to disasters are also enhanced (Gharad, Glaeser and Tsivanidis, 2019). The UN projects that more than half of the planet's population already lives in urban areas, and this number is projected to exceed two-third by 2050 (UNDESA | United Nations Department of Economic and Social Affairs, 2018). This growth is expected to be highly concentrated in India, China and Nigeria, which will together account for 35\% of the increase in urban population between 2018 and 2050.

India's capital city chronicles and delineates the extremes observed in a majority of developing countries-rural inhabitants flocking to major cities in hopes of better livelihoods (Ward, 2018). The Indian economy is fast accelerating. One of the key drivers of this upward trend is the rapid urbanization the country has witnessed in the past few decades (The World Bank, 2011). The census data over the last three periods (1991, 2001 and 2011) reveals an increase in urban population by over 30\%, with a higher projected rate of growth for the next few decades (Ministry of Housing and Urban Affairs, Government of India, 2016). UNDESA (2018) also projects an increase of 416 million in urban population by 2050 in India. While this unabated growth presents a propitious opportunity for the economy, it is imperative to tread carefully. The measure of this situation turning into an opportune one hinges on whether the country is able to provide the required infrastructure and services necessary to match this burgeoning growth (Ward, 2018). Ward (2018) also states that while many urban inhabitants are above the official poverty line in India, non-monetary measures such as access to healthcare and education might actually be better for their rural counterparts. Thus, developing countries house cities as complex urban centers that have the latent potential to provide prosperity for billions.

\subsection{Satellite Cities: A Case of Proliferating Urban Offshoots}

As existing urban centers and megapolises expand with new investments and creation of job opportunities, cities across the globe combat the challenges of urbanization and extreme densification (Valsan, n.d.). The 101st Inter-Parliamentary Conference Resolution (1999) outlines challenges that hinder the growth of metropolitan cities. A few of these include the inadequacy of housing and infrastructure, insufficiency of social services, deteriorating quality of life, traffic congestion and environmental pollution, coupled with burgeoning real estate costs. The implication of this mushrooming population and incommensurate development of infrastructure that leads to socio-economic disparity stresses the need for sustainable city planning measures that pave the way for efficient running of cities (Chrysoulakis, Castro and Moors, 2014). 
Satellite cities were introduced in the 20th century to tackle these challenges and reduce congestion through relocation of people and job opportunities to new developments (Phillips and Yeh, 1987). Introduced by Graham Romeyn, these cities were derived from the idea of Garden Cities, as devised by the planner Ebenezer Howard. Initially conceptualized as dependent cities, they lay close to the parent city but were later decentralized in their design as initiated by the Finnish architect Eliel Saarinen (Deepthi, Shanthipriya and Radhakrishnan, 2020).

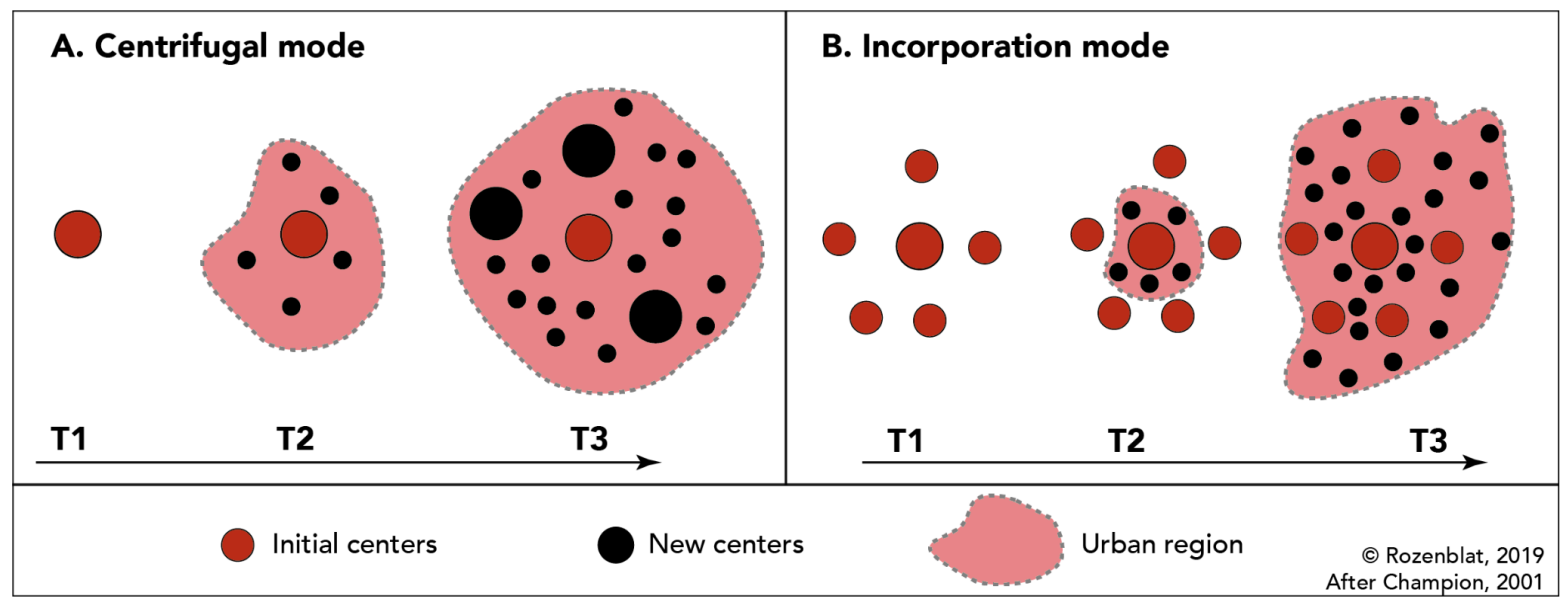

Figure 1. Two Models of Urban Field Growth. Source: Champion, 2001

Urban centers and megacities thus witnessed centrifugal growth along the peripheries, leading to the creation of these cities across the globe in the last few decades (Figure 1.A)(Champion, 2001). Satellite cities thus sprouted as urban offshoots on greenfield sites as a response to unchecked urbanization, providing relief to major cities (Forsyth, 2016). If planned effectively, these cities can help transform the lives of its residents while contributing to the economic growth of a country.

The self-containment of such cities has been a key objective, as noted by Phillips and Yeh (1987), but it has been hard to achieve due to a multitude of reasons, including striking a balance between housing and employment, provision of social services and adequate infrastructure. Otherwise, it would be imperative to provide adequate transportation links between the central and the subsidiary towns; its implications being that the residents of satellite towns commute to the central city for employment opportunities and social activities. This, however, is not a prerequisite to ensure the sustainability of the city as posited by Robert Cervero (1995).

\subsection{Gurugram: Delhi's Pseudo-elite Satellite City}

The effects of unbridled expansion in India's capital city are inevitable-with a swelling population and incessant influx of migrants, New Delhi could become the world's most populated city by 2028 (UN DESA I United Nations Department of Economic and Social Affairs, 2018). As a consequence of the strains of unchecked urbanisation, the city gave rise to four satellite cities along its peripheral boundary, namely, Gurugram, Faridabad, Noida and Ghaziabad in the form of the National Capital Region (NCR) of Delhi (World Energy Council: Indian Member Committee, 2010)(Figure 2). 


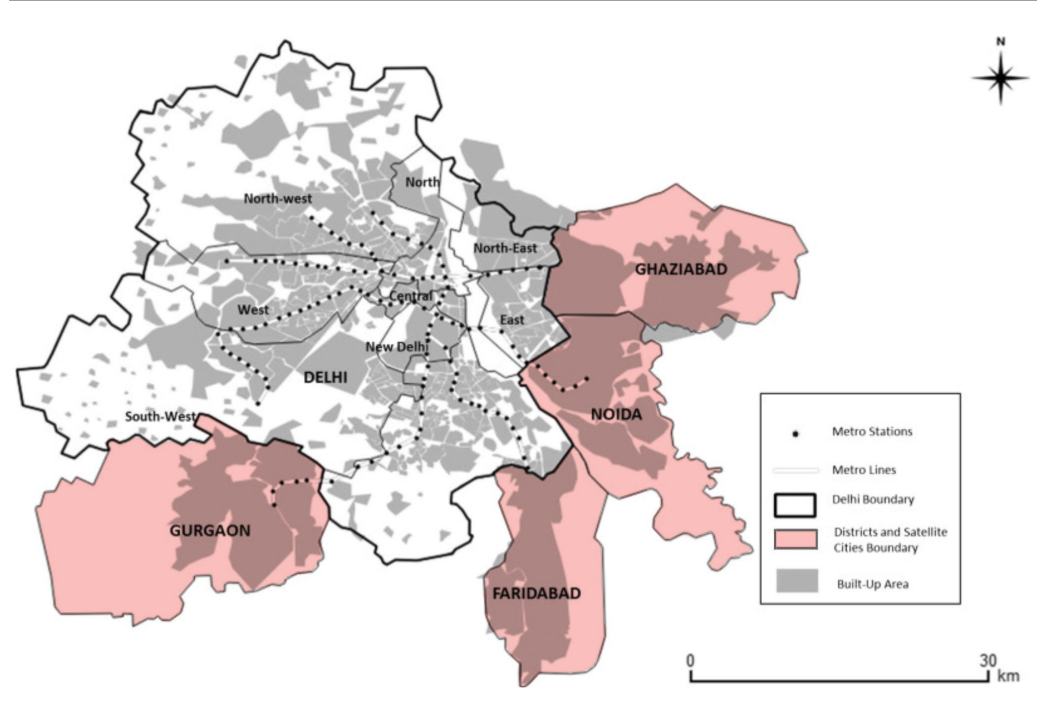

Figure 2. Gurugram: One of Delhi's four satellite cities. Source: Goel and Tiwari (2016)

Gurugram, once a small-scale agriculture-based settlement, is now a city of polarities. Located roughly 30 $\mathrm{km}$ from the center of Delhi, the city is synonymous with the typical idea of urban India, with sprawling skyscrapers, malls, headquarters of MNCs and businesses, and affluent housing complexes. But while the slick urbanization of the city has successfully transformed its image into that of the Millenium City of India, as one scratches the surface, it is anything but. Existing as a city of incongruity, disparity and extremes, Gurugram houses a glaring income disparity, pockets of development and private townships equipped with world-class infrastructure that exist starkly beside temporary shelters built by inhabitants and underdeveloped areas marked by squalor (Majumdar, 2018). The city represents a complexity that may be rampant in satellite cities in developing countries across the globe.
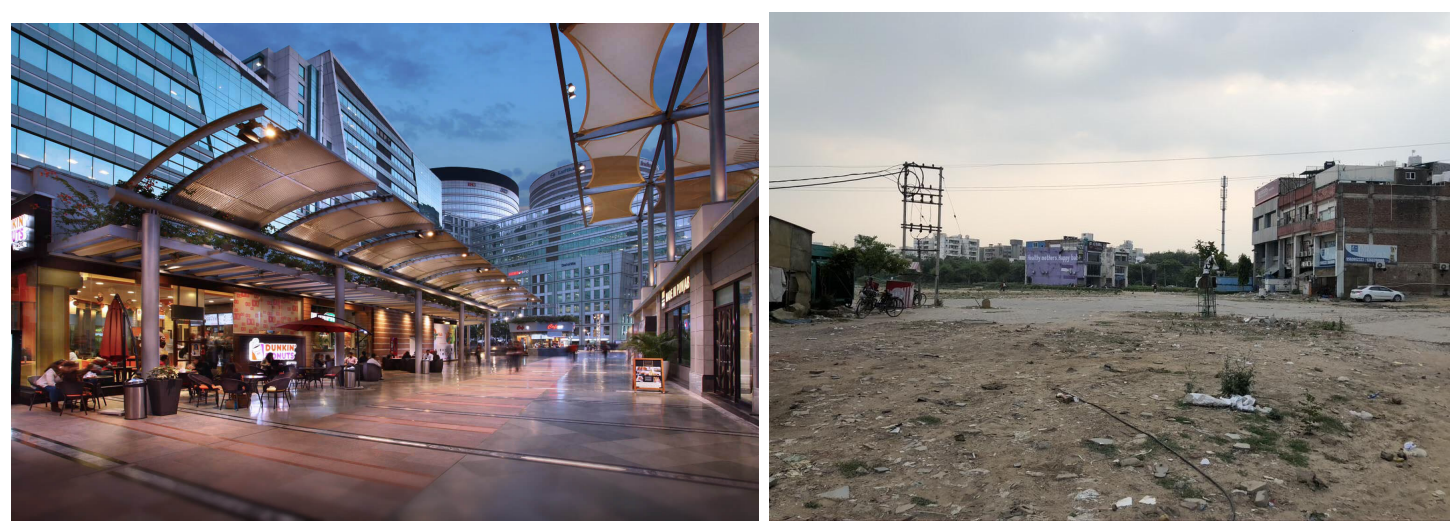

Figure 3. Gurugram's Privatized Urbanscapes (left) and Undeveloped Civic Infrastructure (right). Source: Black \& White Engineering (left); Author (right).

A number of factors have contributed to the current state of the city. Witnessing a prodigious increase in population over the last few decades, the city's population grew from a mere thousand to more than 1.5 million in 2011 (Government of Haryana, 2011). This unprecedented growth strained the already deficit infrastructure. Further, the development of the required infrastructure failed to precede the private development that soon followed to cater to the burgeoning population. Another vital reason behind the city's challenges lies with the Public-Private Partnership (PPP) model that failed to be implemented successfully (Times of India, 2013). The government took a backseat in the development of the city as the country's first megaproject. Private developers and government agencies developing the city's civic infrastructure were not in tandem, leading to a lack of urban development and planning failures. 
The city is hostile in its design (or lack thereof). Without a master plan, there was no demarcation of zones for residential, commercial and civic infrastructure, leading to the inequitable and arbitrary sprouting of private development in the city (Narayan, 2015). Gurugram is also notorious for the bad press it elicits-a media favourite with headlines such as "Gurgaon: A Cesspool of Crime" (Sharma, 2019) or "Gurgaon: How not to Build a City" (Kumar and Misra, 2012), but not without reason. An acute lack of footpaths, sidewalks and pedestrian crossings have elicited a car-dominated city, which discourages pedestrian movement and increases traffic load. A public transportation system does not exist beyond the privatised Rapid Metro with limited connectivity. Additionally, the city is frequented by drainage and sewage issues and erratic power supply, and its pollution rivals Delhi's even though Gurugram's population is a fraction of that of the capital city (The Guardian, 2012). The city starkly lacks parks, open spaces and community hubs. With privatized development, the existing public spaces only serve a select socio-economic stratum, lacking all-inclusive spaces for communities (Figure 3). Adding to the woes of the citizens, the dimly lit streets, and desolate stretches of roads without CCTV surveillance and police personnel have also deemed it to become NCR's crime and rape capital (Sharma, 2019). The result is a city safe within gated communities, where the elite manage to pay their way out of these shortcomings but the vulnerable bear the brunt that accompanies this shambolic development.

Gurugram is far from being the ideal equitable and egalitarian city. However, despite the shortcomings, the exponential growth and copious amounts of private development illustrated by the city only proves its desirability.

\subsection{The Public Sphere and Communities}

State of Working India 2021 - One year of COVID-19 (Azim Premji University, 2021) outlines the impact of COVID-19 in India. With increased informality, a severe decline in earnings and increase in penury, an additional 230 million fell below the poverty line. Amongst these, women were the most disproportionately affected-losing employment more than their male counterparts; nearly half of salaried workers experienced a shift to the informal sector, and the poorest households experienced the highest losses accompanied with a detrimental shift in congested living conditions. The pandemic invariably transformed how citizens live, work and play, and their relationship with the urban environment. Public spaces earlier deemed 'leisurely' became a prerequisite for cities, particularly for the underprivileged that have even more limited options, post the pandemic. (Nagarika Research, 2021). Public spaces thus are an essential tool in the response to the virus to either limit the spread, or to provide people the necessary space to carry out their livelihood and relax, while ensuring adequate space for physical distancing (UN-Habitat, 2020).

As vehicular traffic on the roads decreased, countries across the globe readily adapted to pedestrian-friendly cities, temporarily or permanently re-allocating road space to bicycles, and expanding pavements to facilitate safe and easy pedestrian movement. However, in developing countries, the pandemic highlighted the systematic failures in planning of urban spaces. For example, Delhi's urban spaces such as Sunder Nursery (a 16th century heritage park) fostered a sense of community resilience, while the residents of Gurugram were faced with the egregious reality of a city ill-equipped with civic and social infrastructure. The polarity of uneven distribution of public spaces for people across the socio-economic spectrum was highlighted at this time more than ever. Going forward, it thus becomes essential to build cities resilient in their planning, which would lead to the formation of inclusive and equitable communities. 


\section{Project Anubhuti}

\subsection{The Project}

During the pandemic in 2020, Better Habitat Foundation, a non-profit organization, came forth with a mission to develop a more egalitarian Gurugram. In collaboration with a design team consisting of Ananya Sethi, Mannat Bains and Mehar Kochhar, Project Anubhuti was conceptualized. Anubhuti, which translates to 'experience' in Hindi, set out to change the perception of urbanscapes that were previously deemed inequitable, unsafe and underdeveloped by the citizens. The organisation thus set out to improve the socio-cultural environment and infrastructure, as a response to the issues faced by the residents.

\subsection{Methodology}

This research follows a qualitative approach, through an in-depth analysis of existing conditions, issues and challenges faced by satellite cities in developing countries. In an attempt to successfully ideate, design and execute Project Anubhuti, case studies set in developing countries (Colombia and Myanmar) were selected (World Population Review, 2021). This selection enables parallels to be drawn between the site selected for the research and the implemented projects. The case studies range from regeneration of alienated defunct urban blocks, to transformation and reactivation of obsolete alleyways. The analysis of their successes, failures or shortcomings would better inform design decisions: subsequently leading the project to become an urban catalyst as it envisages to be.

\subsection{Case Studies}

\subsubsection{Regeneration of Public Space through Tactical Urbanism in Bogotá}

In 2019, Bicistema, an architecture and urbanism studio intervened in four strategic locations in Colombia's capital city Bogota as a part of the 'Me Muevo Segura' Tactical Urbanism project (Bicistema Architecture And Urbanism Team, 2021). Translating to 'I move safely', in collaboration with the District Secretary for Women, the campaign aimed to tackle the unequal access to public space through tactical urbanism to form egalitarian, gender-diverse and sustainable urbanscapes.

Me Muevo Segura laid strong emphasis on the creation of an inclusive society in Bogota, which is heavily stratified on a socio-economic basis, through prevention of violence and harassment against women. Four 'unsafe' localities were identified as critical zones for intervention-Suba, Kennedy, Teusaquillo, and Tunjueito (Baraya, 2020). Following this, a five-phase process was deployed:

1. Diagnosis - Analysis and diagnosis of existing problems and conditions using qualitative and quantitative data.

2. Participatory Design - Collaborative design workshops and proposal presentations to all stakeholders for the identified problem.

3. Execution - Joint execution of the designs.

4. Evaluation - Measurement of results and evaluation of impact.

5. Sustainability - Fostering sustainability of the interventions over time.

While the project prioritized activation of urban scapes in desolate zones, prominence was also given to the upgrade of bicycle tracks, infrastructure, roads, pedestrian and public transport as backbones of the interventions that would lead to the creation and activation of these urbanscapes. In order to achieve this objective, Bicistema employed tactical urbanism-low-cost, scalable and easy-to-implement initiatives in the short term that successfully catalyse long-term changes. 

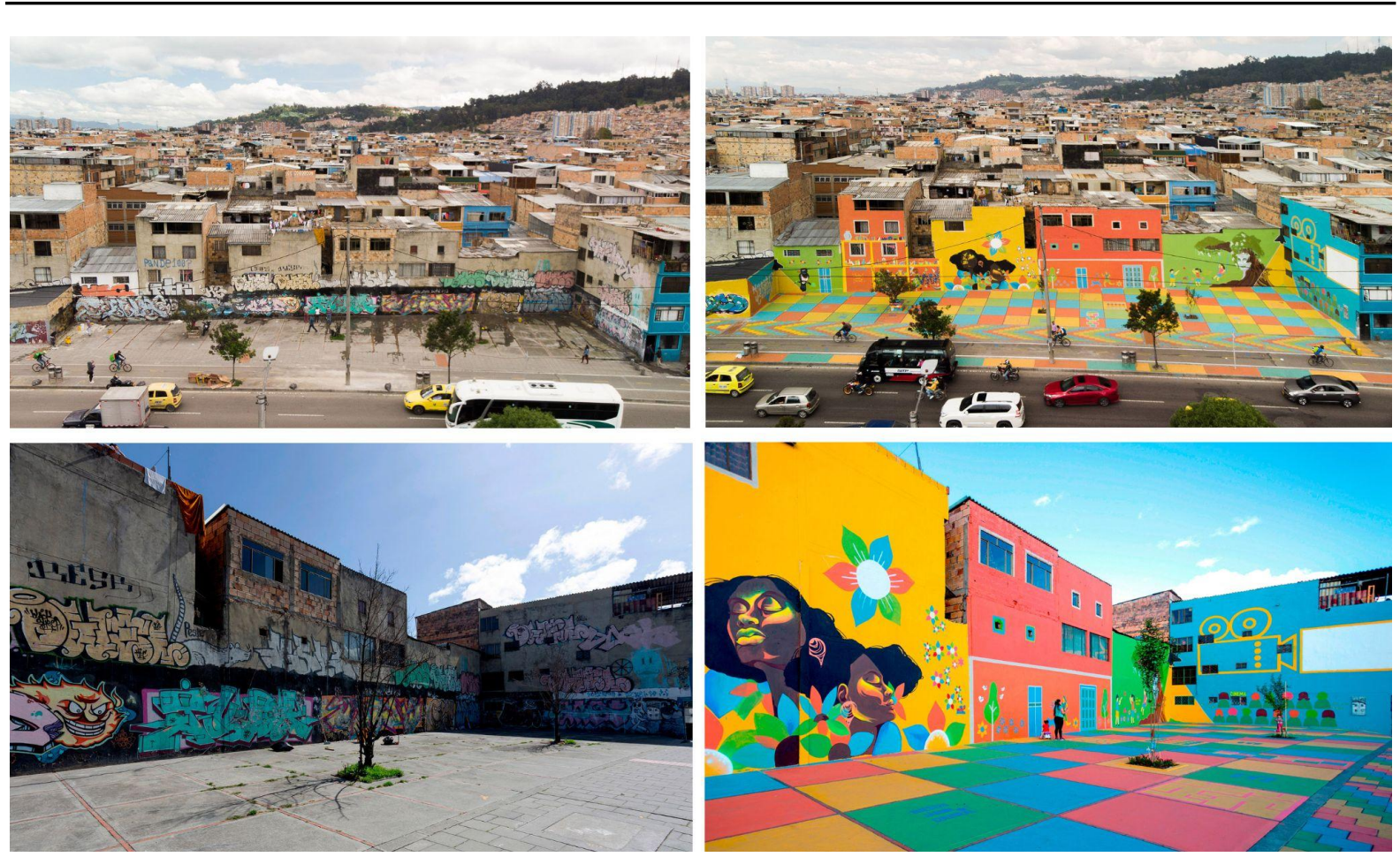

Figure 4. Nuestro Jardin Cultural: Before and After. Source: Bicistema Architecture And Urbanism Team, 2021.

Nuestro Jardin Cultural or Our Cultural Garden, is one of many interventions located in the Suba district of Bogota. An unused street corner of $1140 \mathrm{sq} \mathrm{m}$ that previously housed an uninhabited zone for crime and graffiti was soon transformed into an open-air cultural center. Engagement and participation by local residents and stakeholders during the five stages of the proposal led to the successful reclamation, renovation and regeneration of a space otherwise deemed unsafe. The project was conceptualized as an open-air urban cultural center, which was supported by the city's mobility infrastructure in the form of cycle tracks. The execution involved a team of seventy-two people who helped clean, disinfect, plant trees and flower beds, and paint murals and games on facades and the street. It soon became host to a variety of cultural events. A cinema wall was also incorporated to enable movies to be projected at night. This project was conceived as a pilot to evaluate the potential of the scalability, replicability and sustainability of such interventions.
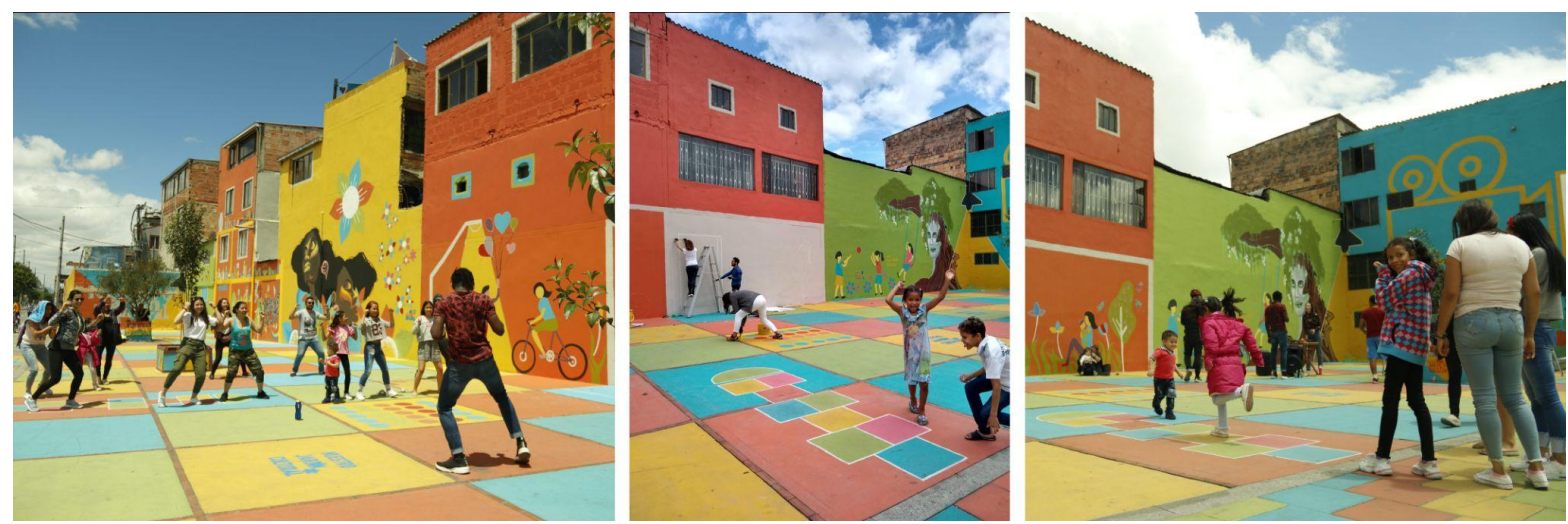

Figure 5. Activated Urban Space. Source: Bicistema Architecture And Urbanism Team, 2021. 


\subsubsection{Yangon's Back Alley Urban Renewal}

Mahabandula Garden exists as Downtown Yangon's only public park. As Myanmar's largest city, Yangon's public spaces are wanting. The amount of green space per person has gone down by a staggering $40 \%$ in 25 years (Chann, n.d.). While the World Health Organization (2010) recommends 100 sq.ft. of urban green space per person in a city, a person in Yangon had access to only 30 sq.ft. of green space in 1990, which has now depleted to an alarming 4 sq.ft. in 2014.

To tackle this issue, in 2016, Doh Eain, a not-for-profit social enterprise came up with a rather astute solution. The city of Yangon was laid out in a grid pattern in the 19th century-15-feet-wide alleys were sandwiched between buildings to serve as utility zones, equipped with open gutters and underground sewers. Over the next century, these alleys transformed into trash-strewn, fetid dumping areas that were subjected to severe neglect by the city and its residents (Horner, 2019). Doh Eain realized the latent potential these alleys withheld. The 150 back alleys, $250 \mathrm{~m}$ long and $5 \mathrm{~m}$ wide, would free up collective urban space that was 6.7 times the area of Mahanbadula Garden (Roell, 2020).

180 alleyways makes 6.7 Mahabandula Parks!!
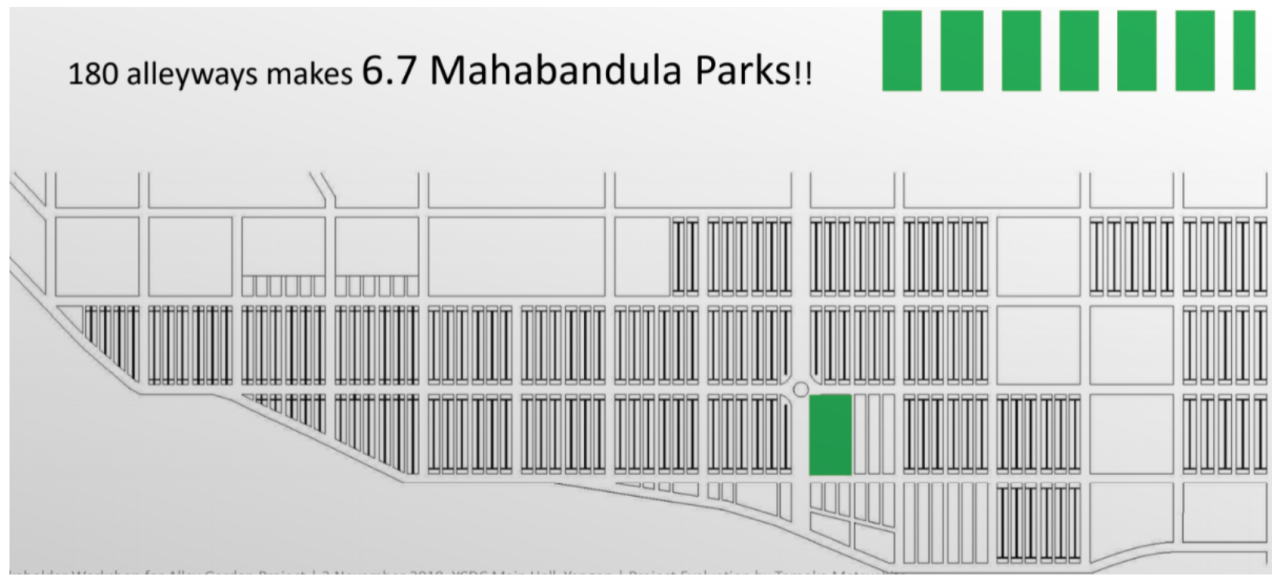

Figure 6. Yangon's 150 alleyways equate to 6.7 Mahanbadula Parks. Source: Roell, 2020.

Initially, the project was met with resistance and scepticism by residents, who were uncertain about its merit. However, after the first mural painting workshop was organized for children in the neighbourhood, the idea landed, as the drab and dreary alley walls were transformed into a freshly painted block. Now cleared of the four-foot-high trash rubble, residents applauded the work. The mayor visited to witness the transformation and $\$ 60,000$ was crowd-funded in a span of three months upon recognising the potential impact the project would have on Yangon's communal life.
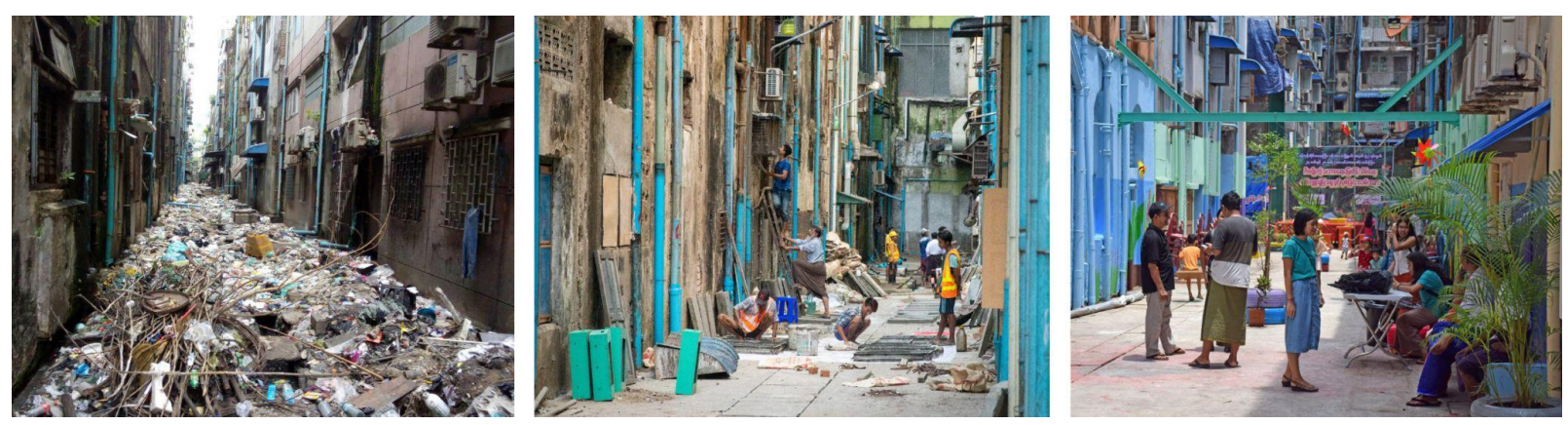

Figure 7. Yangon's Back Alley Urban Renewal Process. Source: Roell, 2020. 

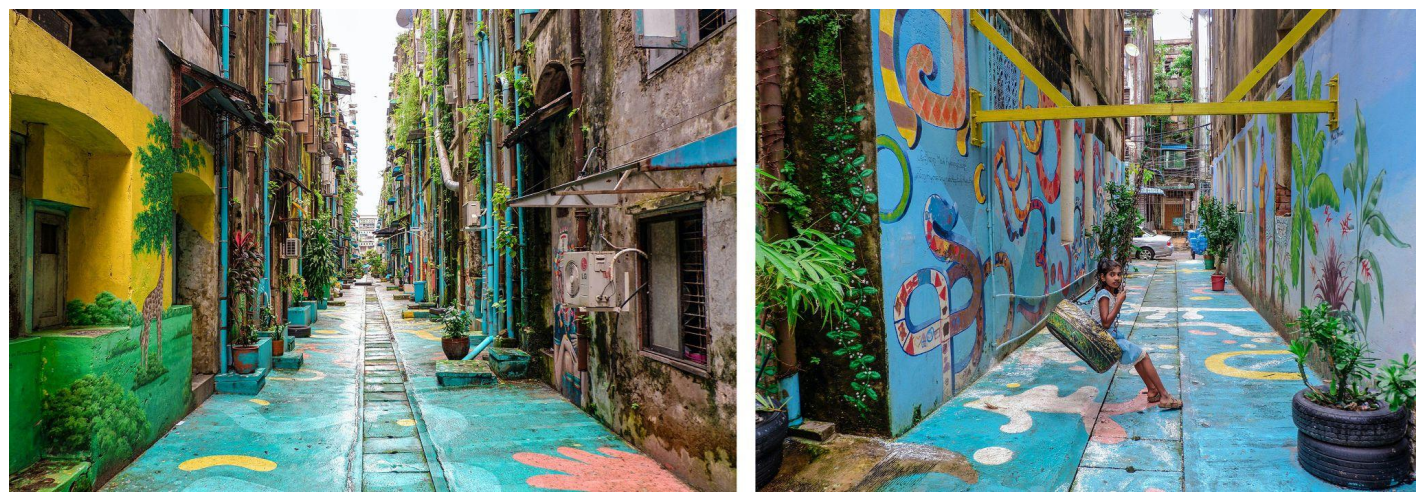

Figure 8. Yangon's Back Alley Urban Renewal Process. Source: Horner, D. (2019).

The Back Alley urban renewal process engaged the stakeholders with a community-led initiative involving participatory design practices, community-building exercises and long-term maintenance initiatives. Additional revenue generated through organized walking tours and volunteer impact days was utilized for the upkeep of the alleyways.

The focal point of the placemaking initiatives was centered around the most vulnerable groups-women and children. Alleyways were equipped with elements most important to the locals-playgrounds and outdoor exercise equipment, gardens and seating, and enhanced by wall murals and street art. Together, these elements were instrumental in rebuilding Yangon's sense of ownership and perception of urban space, thereby transforming their relationship with it. Additionally, assessments of the first six transformed back alleys in 2018 reported a positive impact, increasing alleyway use by $50 \%$.

\subsection{The Site: Existing Conditions}

The project identified would work towards the urban development and regeneration of barren lands of the Sector 55-56 market in Gurugram. The site identified as an urban void for this research was selected on the grounds of the following:

1. Scale, Location and Connectivity - The 50-acre site lies in proximity to Golf Course Road (a prominent landmark road of Gurugram) and two stations of the city's Rapid Metro (which are a kilometer apart), making the site easily accessible and well-connected to major landmarks (figure 9A).

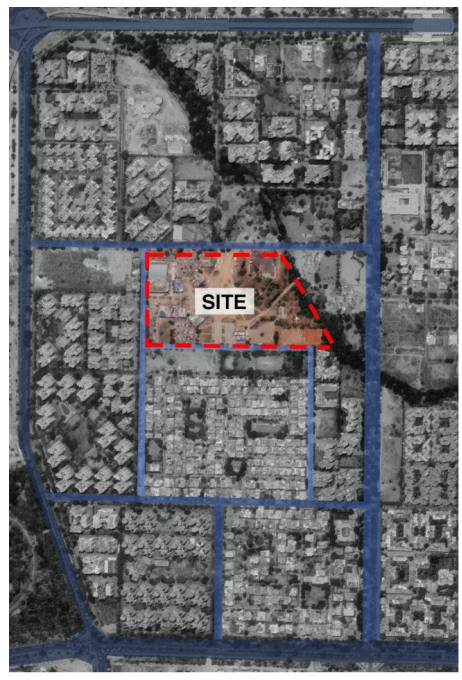

A. ROADS AROUND SITE

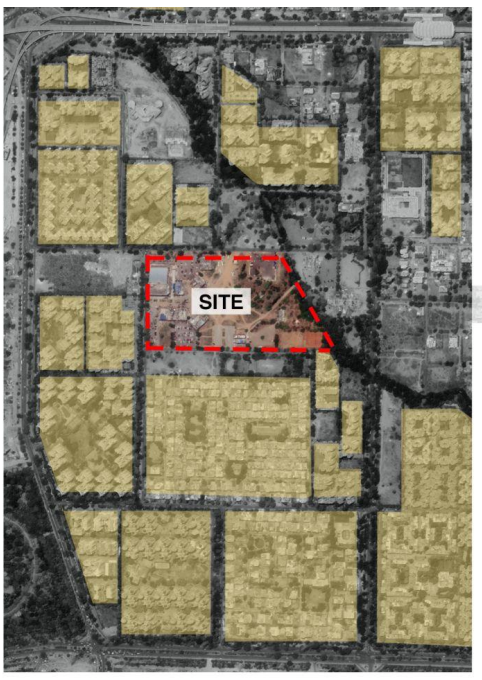

B. BUILT DENSITY AROUND SITE

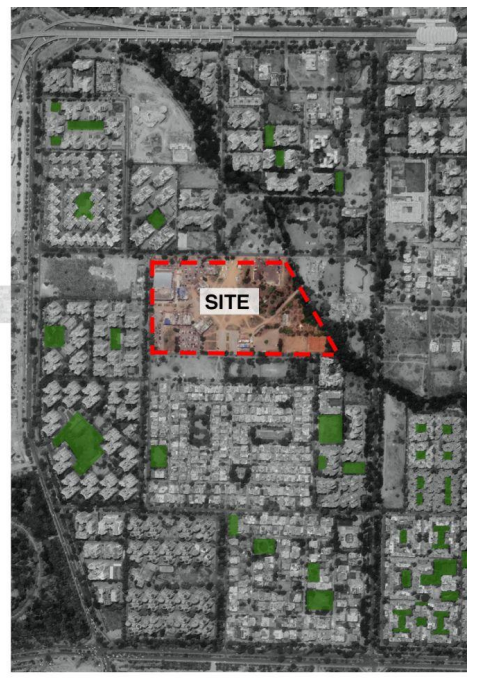

C. GREENS AROUND SITE

Figure 9. Site Context. Source: Ananya Sethi, Mannat Bains, Mehar Kochhar. 
2. Urban Context - Sitting amidst a bustling residential neighborhood, the heavy urban density in the context (figure 9B) is not offset nor supported by substantial greenery (figure 9C).

3. Micro Context - The site is flanked by four independent open markets, along its peripheral arrangement. As reflected in figure 10A, the existing Master Plan between the markets has been earmarked as a green zone. But as reflected in figure 10B, only two markets (market 1 and 2 ) of the four are developed and serve as a vital backbone for the residents housing a wide array of shops, eateries, gyms, healthcare facilities, etc.

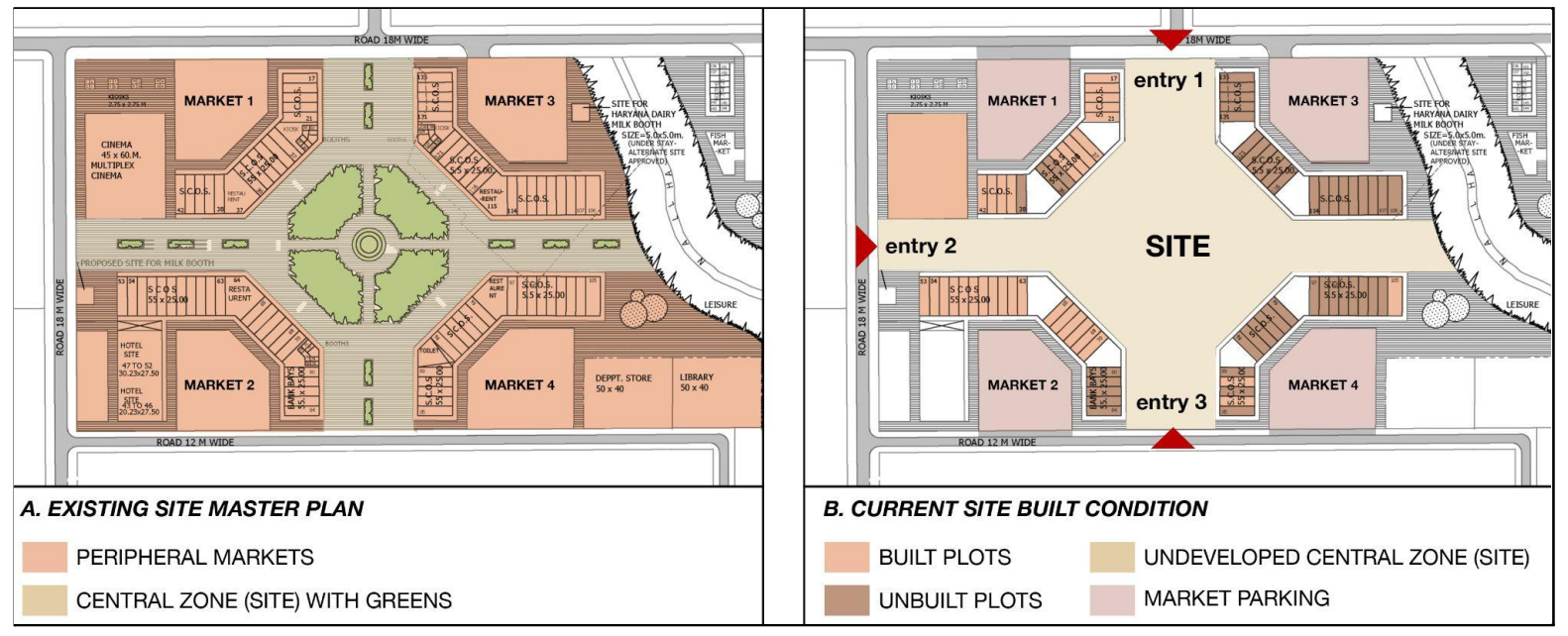

Figure 10. Existing Master Plan (A) and Current Built Conditions (B). Source: Author

4. Inadequacy of Infrastructure - Poor road conditions, unsafe pedestrian access and circulation, insufficient lighting and street furniture result in unsatisfactory market conditions. The central zone currently exists as a barren land that faces the back services of the markets. The zone has become a dumping ground and has not seen development of any sort. With the absence of appropriate lighting and visibility at night, safety at the site is also of concern.

Thus, even though the Sector 55-56 market serves a large number of citizens, it does not function as a space that is inclusive, safe and uplifting for the community.
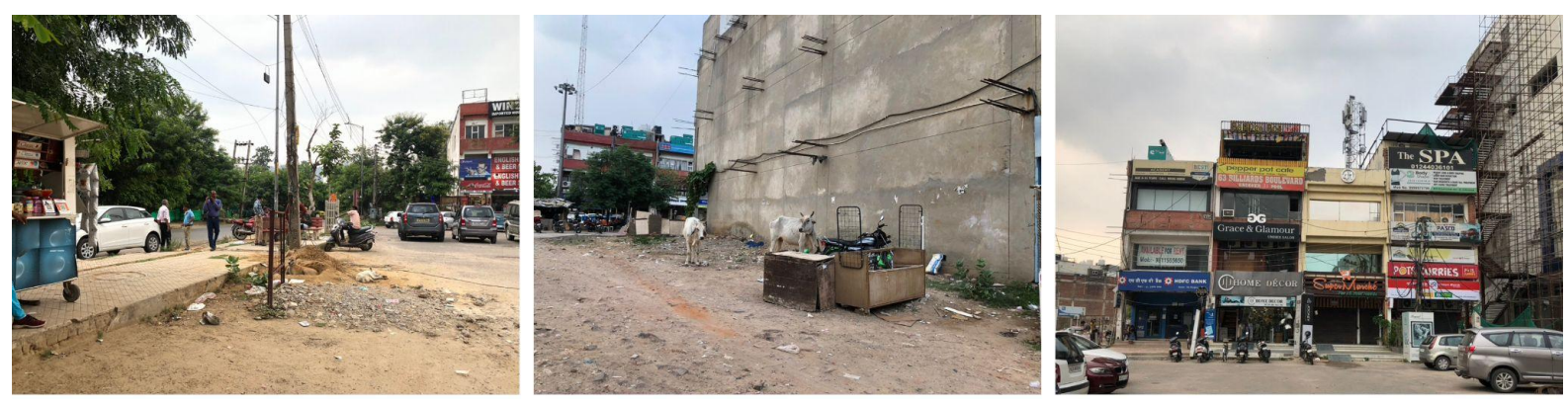

Figure 11.Sector 55-56 Market and Surrounding Infrastructure. Source: Author. 


\subsection{Proposed Intervention}

The masterplan was conceived and driven by existing site conditions. The inadequacy of satisfactory conditions led each stage of the design:

1. Increasing Permeability (Primary and Secondary Entrances) - The success of an urbanscape can be attributed to its permeability. While it is imperative to enhance the ease of accessibility, visibility and engagement of pedestrians, a permeable urbanscape integrates seamlessly with its context, automatically drawing in the stakeholders.

Implementation - The selected site is bound by roads on three sides, enabling three primary entrances to the site (Figure 12A). At the same time, the passageways from the four markets provide secondary site entrances, making the site pervious to draw in curious visitors.

2. Circulation and Axes - Axes as a concept help guide, organize and direct design and subsequently, the journey of a visitor.

Implementation - The primary axis aims to connect opposite sides of the site to encourage pedestrian use (Figure 12B). The secondary axis aims to develop a relationship between the markets. The passageways seamlessly flow into one-another, while also forming a connection with the central site.

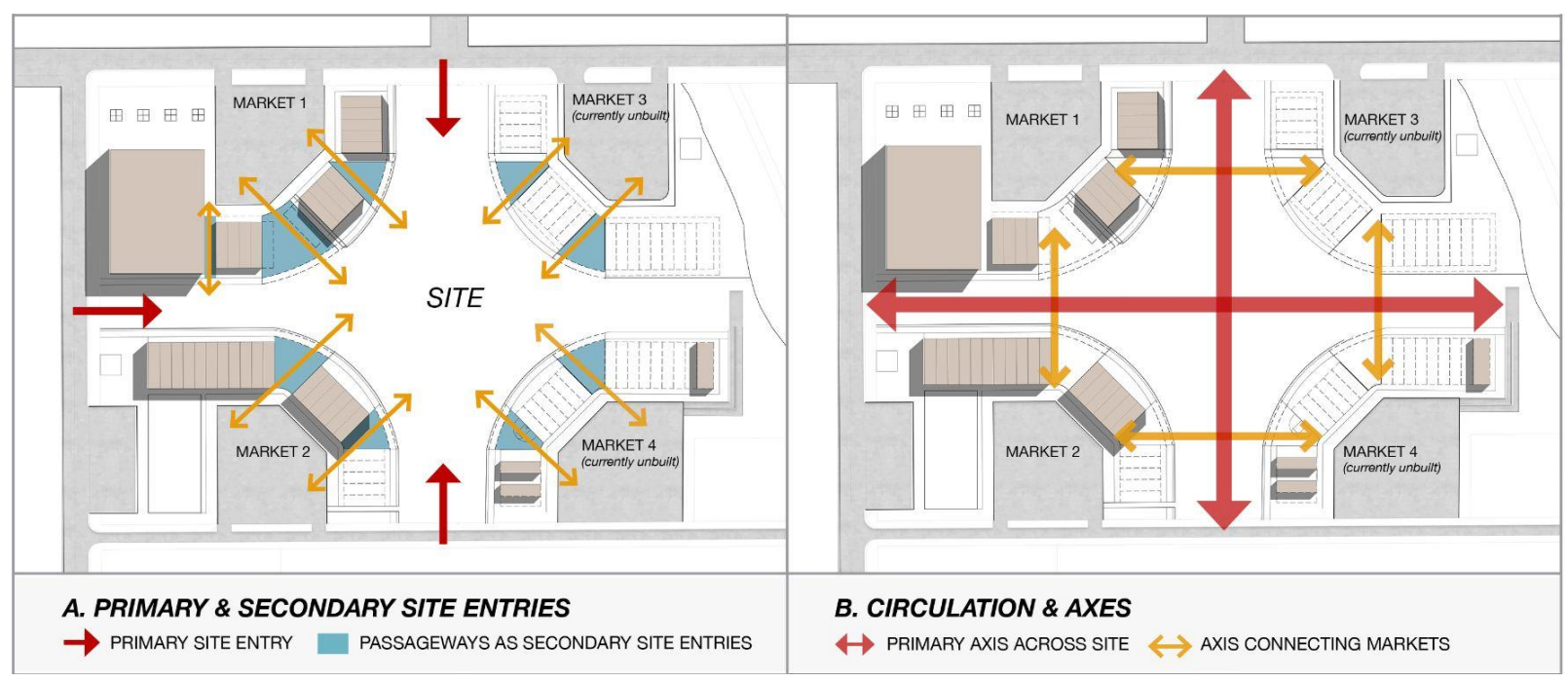

Figure 12. Site-level Concepts. Source: Ananya Sethi, Mannat Bains, Mehar Kochhar.

3. Circulation Routes - It is imperative to attain inclusivity in design through the virtue of including various stakeholders.

Implementation - Three forms of circulation paths were deemed necessary- a jogging track, cycling track and a service vehicle lane. The walking path dissects the site, forming clusters of greens of varying scales while enabling connectivity across and amongst markets. The cycling track is planned along the periphery as a long continuous loop. The two-wheeler service lanes were circumscribed along each market's back edge (Figure $13 \mathrm{~A})$.

4. Greenscapes - Integration of recreational spaces, organized and informal greens in cities lead to the formation of sustainable urban environments while also positively affecting the economic, cultural and ecological benefits, and an improved quality of life for citizens.

Implementation - Gurugram acutely lacks greenscapes in the form of parks and gardens for the public. The lack of greenery around the site provides an opportunity to design a green intervention in the form of 
pockets of greens carved through winding circulation paths, each unique in its identity and scale (Figure 13B).

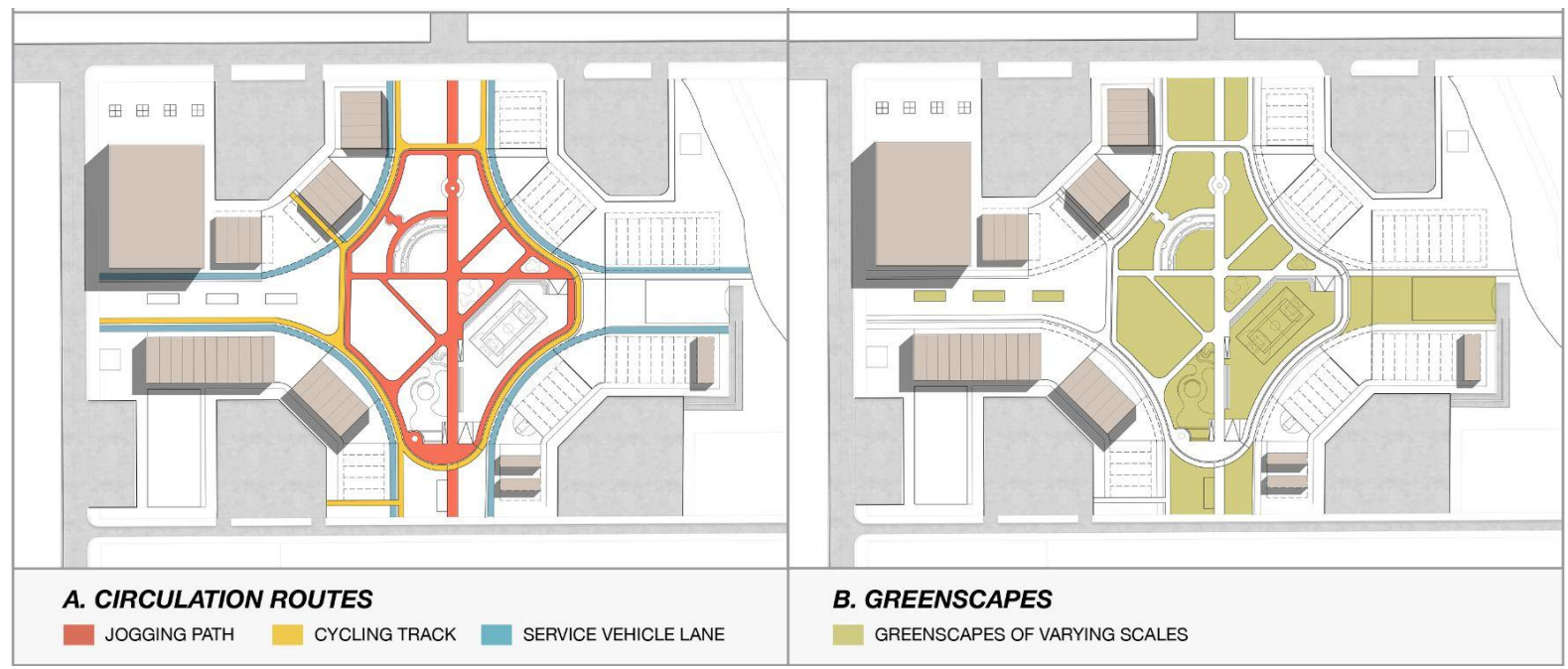

Figure 13. Site-level Concepts. Source: Ananya Sethi, Mannat Bains, Mehar Kochhar.

5. Activating Passageways - Passageways as utilitarian corridors have been long overlooked for their potential to create vibrant urban hubs. An essential part of the design of Project Anubhuti can be attributed to the activation of alleyways. They function as secondary site entrances while also playing a pivotal role in connecting the four independent markets. The focus was on creation of alleys that are habitable and safe, which welcome passersby to both move and linger and gather, whose spatial scales are humane and interactive, and which promote the formation of the identity of a space.

Implementation - The research explores implementation of alleyways as the following:

A. As Community Hubs - Domesticated and more intimate in scale, these alleyways have a specific focus on human interaction, targeting all age and user groups (Figure 14A). The passageway can turn into a hub for various activities and civic engagement. Their volume and scale allows them to host a number of different functions to meet, eat, drink and socialize.

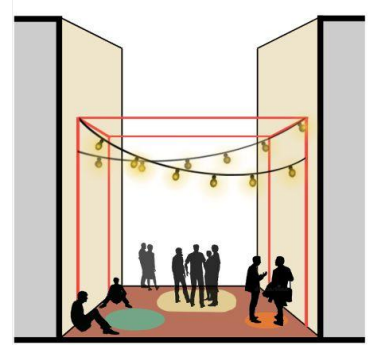

A. COMMUNITY HUBS

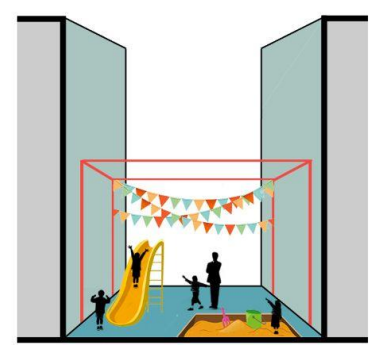

B. ACTIVE ZONES

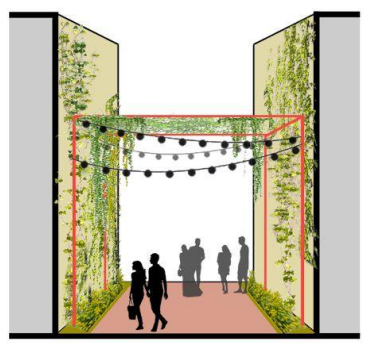

C. GREENSCAPES

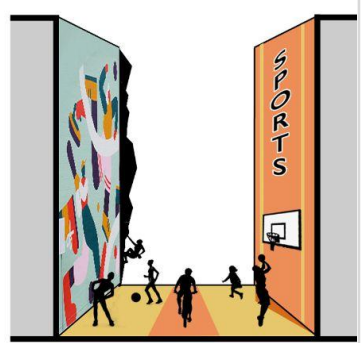

D. PLAYGROUNDS

Figure 14. Passageway Concepts. Source: Ananya Sethi, Mannat Bains, Mehar Kochhar.

B. As Greenscapes - The presence of a green cover radically changes the perception and comfort of the passageway. It becomes a quiet, cool and relaxed place (Figure 14B).

C. As Active Zones - Targeting older children and young adults, a greater volume and scale allows the alley to become a cool and well ventilated space for workouts, a training track, etc. It could also become a supplementary zone for the gyms in the market (Figure 14C). 
D. As Playgrounds - An enclosed yet open, safe and fun space for children to engage in, these alleys are more intimate in scale. Structures, games and other elements turn the space into an adventure, for both children and adults.
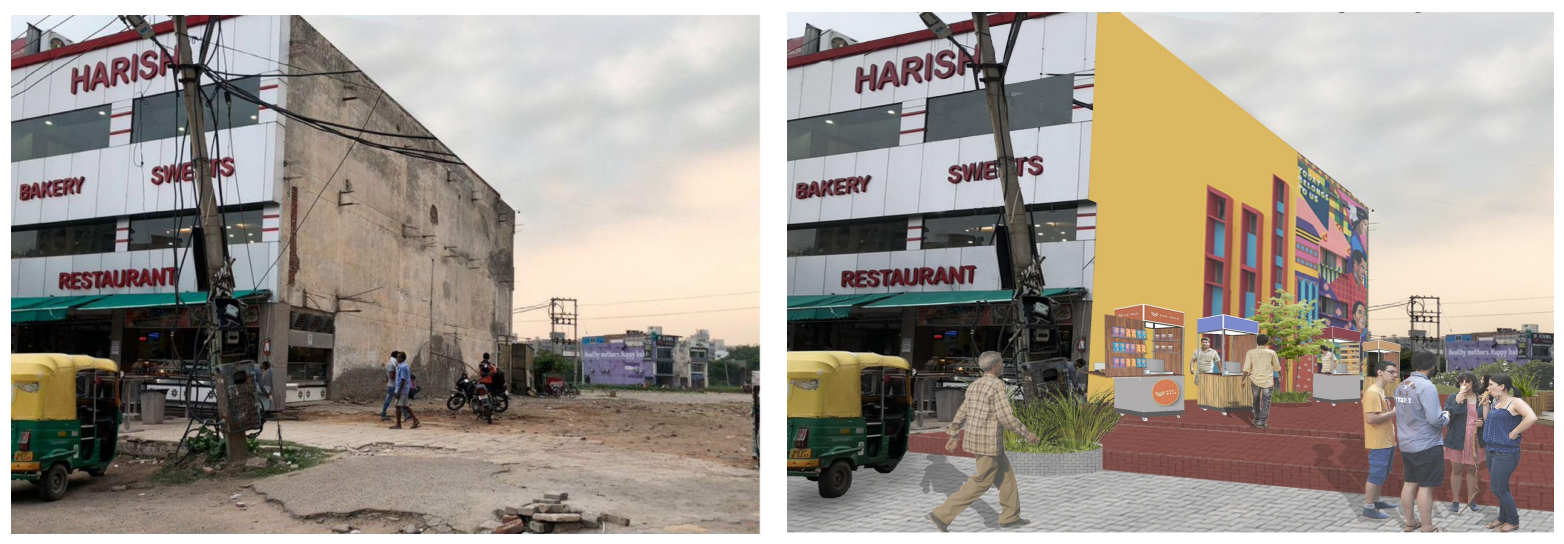

Figure 15. 'Before and After' Market 1 Passageway. Source: Ananya Sethi, Mannat Bains, Mehar Kochhar.
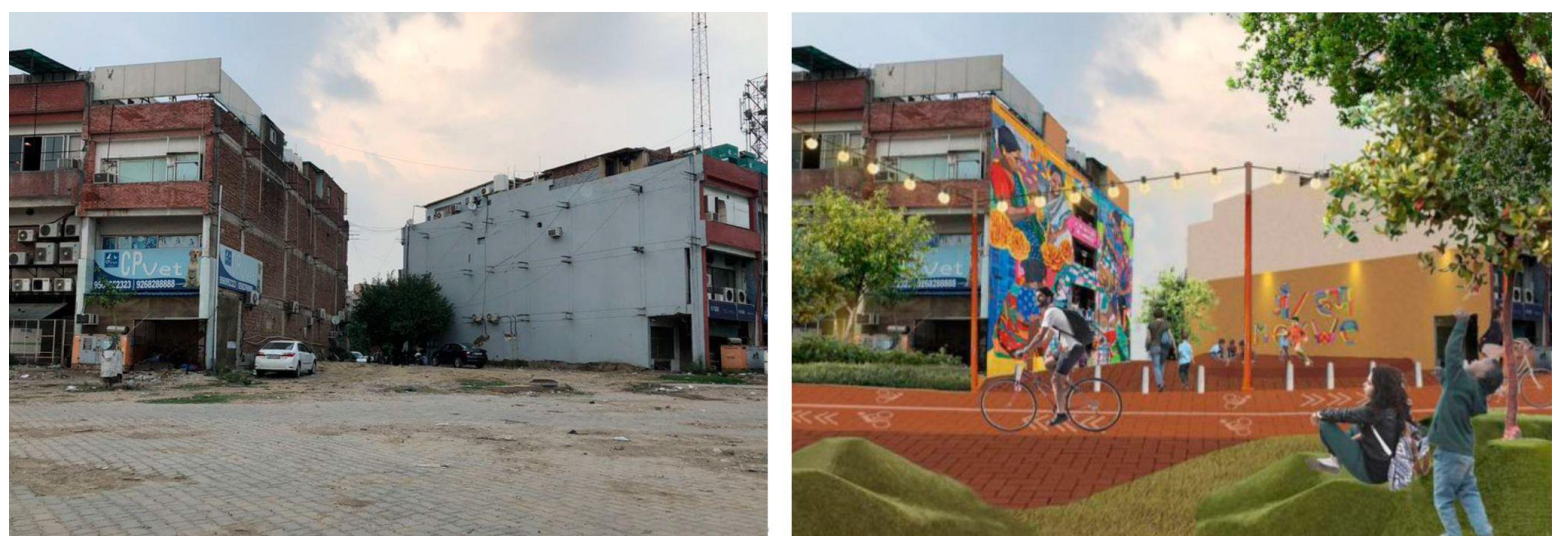

Figure 16. 'Before and After' Market 2 Passageway. Source: Ananya Sethi, Mannat Bains, Mehar Kochhar.

6. Site-specific Program - Following the site study and analysis of the Sector 55-56 market, the masterplan was conceived with the aforementioned strategies as reflected in Figure 15. Entries 1 and 3 on opposite sides of the site follow a linear axis. Entry 2 on the perpendicular axis was envisaged to open into a celebratory plaza. Its strong public character is enhanced by a catenary lighting system. Three communal passageways, i.e., A, B and I (figure 15) from markets 1 and 2 open into this plaza that directs the user to the central greens. The site's green cover has been strategically divided into zones of varying scales and character-from grass mounds to a green amphitheater. These attempt to capture different user groups. Alleyways $\mathrm{H}$ and $\mathrm{G}$, in the form of Playgrounds, are in proximity to the Sports Ground and Children's Play Arena. Project Anubhuti hence attempts to capture all user groups, thereby changing the perception of Sector 55-56 marketspace and transforming it from an urban void into a communal hub that adds to the inclusivity and well-being of the area's residents and visitors. 


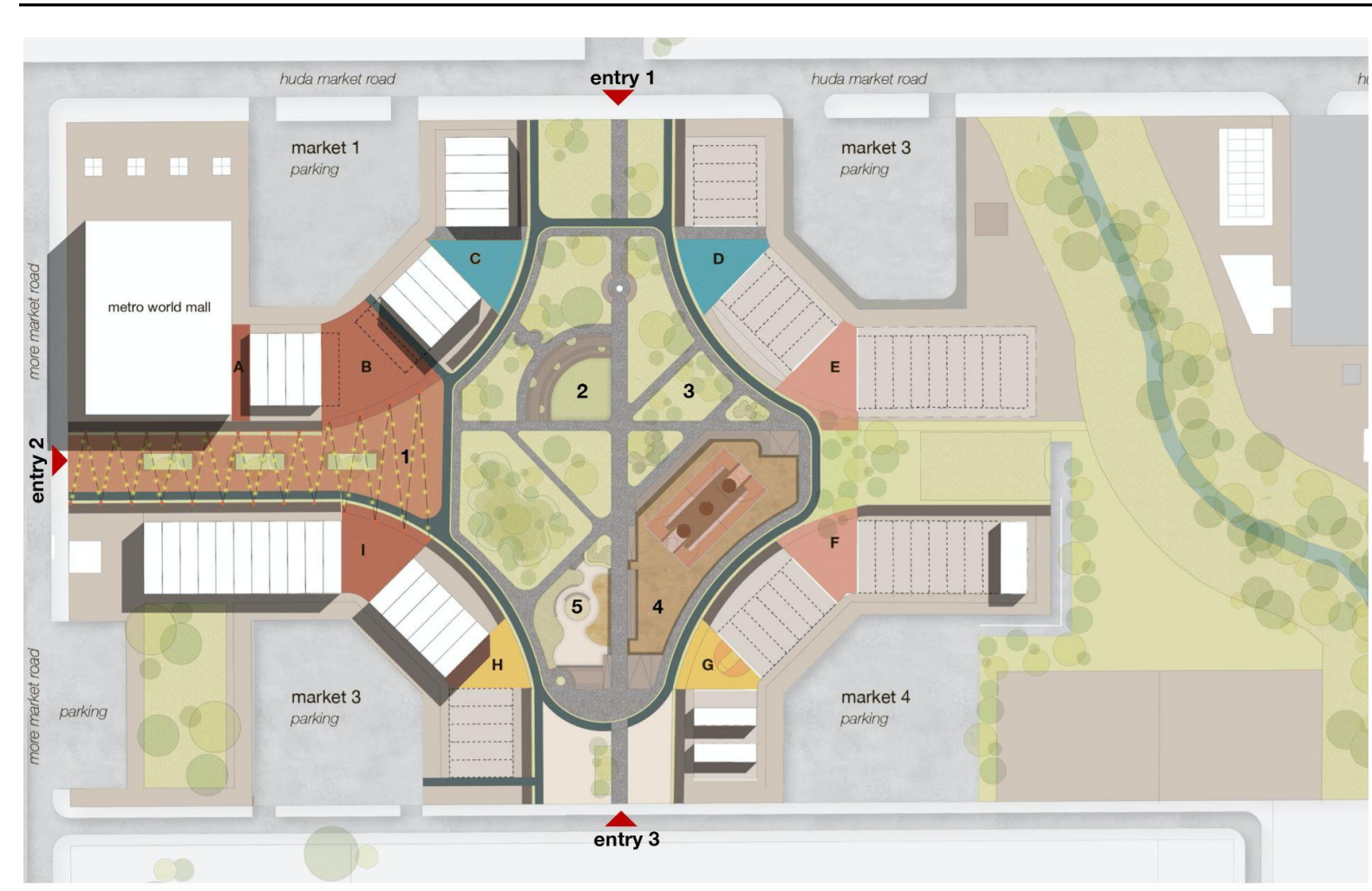

MASTERPLAN KEY:

1. PLAZA | 2. AMPHITHEATRE | 3. GREENSCAPES | 4. SPORTS GROUND | 5. CHILDREN'S PLAY ARENA

\section{PASSAGEWAYS (SECONDARY ENTRANCES) KEY:}

PASSAGEWAY A, B, I - AS COMMINITY HUBS

PASSAGEWAY C, D - AS PLAYGROUNDS
PASSAGEWAY E, F - AS GREENSCAPES

PASSAGEWAY G,H - AS ACTIVE ZONES

Figure 15. Site Master Plan. Source: Ananya Sethi, Mannat Bains, Mehar Kochhar.

7. Tactical Urbanism - Tactical urbanism can be defined as low-cost, short-term and scalable initiatives that have the potential to generate medium and long-term changes (Bicistema Architecture And Urbanism Team, 2021). Focusing on strengthening the relations between the urban fabric and citizens, these interventions are community-led initiatives that are planned, designed and executed in conjunction with the residents. These interventions function as a catalyst towards place-making and hence are an integral part of the proposed design.

\section{Conclusion}

The successful planning, design and implementation of a holistic city is one that requires a thorough understanding of the underlying layers and complexities of physical, social and economic environments. An inclusive, resilient and sustainable city is one that is developed after careful consideration of several factors, including socio-cultural and socio-economic conditions. Intensive work and coordination amongst the administration, policies and investments must be directed towards the same objective (World Bank 2019). This paper covers the implications of rapid urbanization with a focus on developing countries that witness the proliferation of megacities to haphazardly built satellite towns. With a succinct focus on Gurugram, the city's issues, challenges and opportunities are discussed with a clear takeaway-despite an acute lack of vibrant community spaces and civic infrastructure accessible to all amongst other shortcomings, the city will continue swelling in size and population. The COVID-19 pandemic brought forth the importance of people-friendly holistic cities that house egalitarian, uplifting and safe 
community-building public spaces. Urban spaces are no longer viewed as leisurely, ornate environs, but are pivotal in a city's success; they play an essential role in supporting the poorest citizens. As we move towards recovery, cities have a chance to leverage the pandemic's lessons and build resilience.

The analysis of the case studies brought to light the importance of urban development projects and revitalisation on the urban scape, but more importantly, community life. By successfully engaging with the stakeholders during different design phases, the interventions led to a sense of civic pride and ownership, redefining the relationship of the citizens with their environment while also helping develop long-term sustainability of the space.

Gurugram can serve as a model satellite city not just for India, but also for other developing nations if it successfully manages to tap upon these opportunities. The city is teeming with potential for urban interventions with no shortage of urban voids and undeveloped landscapes. The city could adopt various policies and practices to enable the activation and development of the city's urbanscapes. Establishing a program for the development and revitalisation of obsolete urban areas around open markets and businesses would not only increase footfall for businesses, but also pave the way towards a pedestrian-friendly city. The previously adopted Public-Private Partnership model could prove fruitful towards this.

Better Habitat Foundation in its endeavour to build a better Gurugram aims to implement Project Anubhuti in collaboration with government authorities and private organisations. The project is set to be implemented in two stages-a small-scale pilot project around market 1 has been identified to evaluate the scalability, sustainability and success of the intervention. Upon collection of adequate funds and execution of the pilot, it will become an indicator of Project Anubhuti's overall communal impact. Amendments to the Master Plan will be made following an analysis of its successes and failures, engaging the citizens to determine the impact, after which the intervention would be implemented on the 50 -acre site, changing the Anubhuti (perception) and relationship of the residents with their physical environment.

\section{References}

Amirtahmasebi, R., Banco Mundial, Orloff, M., Wahba, S. and Altman, A. (2016). Regenerating Urban Land: a Practitioner's Guide to Leveraging Private Investment. [online] Washington, D.C.: World Bank Group, Cop. Available at: https://openknowledge.worldbank.org/handle/10986/24377 [Accessed 15 Jan. 2021].

Azim Premji University (2021). State of Working India 2021 - One Year of Covid-19 Centre for Sustainable Employment. [online] Available at: https://cse.azimpremjiuniversity.edu.in/wp-content/uploads/2021/05/State_of_Working_In dia_2021-One_year_of_Covid-19.pdf.

Baraya, S. (2020). Renovation and Regeneration of Public Space through Tactical Urbanism with a Gender Focus in Bogotá. [online] ArchDaily Colombia. Available at: https://www.archdaily.co/co/933210/renovacion-y-regeneracion-de-espacio-publico-median te-urbanismo-tactico-con-enfoque-de-genero-en-bogota [Accessed 1 Sep. 2020].

Bicistema Architecture And Urbanism Team (2021). Tactical Urbanism Pilot: Me Meuvo Segura I Replicability Manual. [online] TUMI (Transformative Urban Mobility Initiative). Available at: https://www.transformative-mobility.org/assets/publications/Replicability-Manual_Technical -Urbanism_EN_TUMI_2021.pdf [Accessed 1 Aug. 2020]. 
Black \& White Engineering (n.d.). DLF CyberHub. Black \& White Engineering. Available at: https://www.bw-engineering.com/portfolios/dlf-cyberhub/.

Cervero, R. (1995). Sustainable new towns. Cities, 12(1), pp.41-51.

Champion, T. (2001). Handbook of Urban studies, Chapter 9: Urbanization, Suburbanization, Counterurbanization and Reurbanization. London ; Thousand Oaks, Calif.: Sage.

Chann, Y. (n.d.). Green Spaces in Yangon: Towards a Greener City for All. [online] Available at: https://themimu.info/sites/themimu.info/files/documents/Policy_Brief_Green_Space_in_Ya ngon_Towards_Greener_City_for_All_ENG.pdf [Accessed 1 Sep. 2020].

Chrysoulakis, N., Castro, E.A. de and Moors, E.J. (2014). Understanding Urban Metabolism: A Tool for Urban Planning. Routledge.

Deepthi, S., Shanthipriya, Dr.R. and Radhakrishnan, Dr.S. (2020). ASSESSING LINKAGE BETWEEN THE PARENT CITY AND SATELLITE TOWNS: A CASE STUDY OF RAMANAGARA AND HOSKOTE-KARNATAKA. Journal of critical reviews, 7(09).

Forsyth, A. (2016). Revitalizing Places: Improving Housing and Neighborhoods from Block to Metropolis. dash.harvard.edu. [online] Available at: https://dash.harvard.edu/handle/1/29312102 [Accessed 15 Sep. 2021].

Gharad, B., Glaeser, E. and Tsivanidis, N. (2019). Cities in the Developing World.

Goel, R. and Tiwari, G. (2016). Access-Egress and Other Travel Characteristics of Metro Users in Delhi and Its Satellite Cities. IATSS Research, [online] 39(2), pp.164-172. Available at: https://www.researchgate.net/publication/283084732_Access-egress_and_other_Travel_Ch aracteristics_of_Metro_users_in_Delhi_and_its_Satellite_Cities [Accessed 19 Apr. 2020].

Government of Haryana (2011). Demography / Gurugram / India. [online] Government of Haryana: Gurgaon. Available at: https://gurugram.gov.in/about-district/demography/ [Accessed 15 Sep. 2021].

Horner, D. (2019). Yangon's alleys get a makeover from this urban design group. [online] Lonely Planet. Available at:

https://www.lonelyplanet.com/articles/yangon-organisation-cleaning-up-city [Accessed 15 Oct. 2020].

Inter-Parliamentary Union. (1999). The Problem of Metropolitan Areas: a Global Challenge to Which Parliamentarians Must Respond in Terms of Urban Civilization and Democracy. [online] Available at: http://archive.ipu.org/conf-e/101.pdf [Accessed 15 Sep. 2021].

Kumar, K.P.N. and Misra, U. (2012). Gurgaon: How Not To Build A City. [online] Forbes India. Available at: https://www.forbesindia.com/article/real-issue/gurgaon-how-not-to-build-a-city/33444/1 [Accessed 16 Sep. 2021].

Majumdar, P. (2018). The Eclipse of a Satellite City. The Hindu: Business Line. [online] 10 Mar. Available at: https://www.thehindubusinessline.com/blink/know/the-eclipse-of-a-satellite-city/article219 87724.ece1 [Accessed 15 Sep. 2020]. 
Ministry of Housing and Urban Affairs, Government of India. (2016). Urban Growth : Ministry of Housing and Urban Affairs, Goverment of India. [online] Available at: http://mohua.gov.in/cms/urban-growth.php [Accessed 10 Sep. 2020].

Nagarika Research (2021). Nagrika - City Futures: Places in Our Spaces. [online] Nagrika. Available at: https://www.nagrika.org/covid19-response/cityfutures-placesandspaces.

Narayan, S. (2015). Gurgaon Is an Example of How Not to Urbanise India. Hindustan Times. [online] 10 Aug. Available at: https://www.hindustantimes.com/columns/gurgaon-is-an-example-of-how-not-to-urbanise-i ndia/story-KqAcFBWI8jp62fCvKTEPwK.html [Accessed 8 Nov. 2020].

Phillips, D.R. and Yeh, G.O.A. eds., (1987). New Towns in East and South-east Asia : Planning and Development. Hong Kong: Oxford University Press.

Roell, E. (2020). Yangon's Alley Garden Project. [online] The City at Eye Level. Available at: https://thecityateyelevel.com/stories/yangons-alley-garden-project/.

Rozenblat, C. and Champion, T. (n.d.). Two Models of Urban Field Growth. https://serval.unil.ch/resource/serval:BIB_DD7D4801A8D4.P001/REF. Available at: https://journals.openedition.org/cybergeo/docannexe/image/35411/img-2.png [Accessed 5 Jun. 2020].

Sharma, S. (2019). Gurugram - a Cesspool of Crime. [online] The Tribune India. Available at: https://www.tribuneindia.com/news/archive/haryanatribune/gurugram-a-cesspool-of-crime -719489 [Accessed 16 Sep. 2021].

The Guardian (2012). Gurgaon, the Luxury Delhi Satellite City at Risk of Drowning in Its Own Sewage. [online] The Guardian. Available at: https://www.theguardian.com/world/2012/jun/05/urban-india-gurgaon-water-electricity [Accessed 3 Mar. 2021].

The World Bank (2011). Urbanization in India. [online] World Bank. Available at: https://www.worldbank.org/en/news/feature/2011/09/22/india-urbanization.

Times of India (2013). A Good Example of Large-Scale Public-Private Partnership But... Times of India. [online] 22 Aug. Available at: https://timesofindia.indiatimes.com/city/gurgaon/a-good-example-of-large-scale-public-priv ate-partnership-but-/articleshow/21968167.cms.

UN DESA | United Nations Department of Economic and Social Affairs. (2018). Around 2.5 Billion More People Will Be Living in Cities by 2050, Projects New UN Report / UN DESA / United Nations Department of Economic and Social Affairs. [online] Available at: https://www.un.org/development/desa/en/news/population/2018-world-urbanization-pros pects.html [Accessed 23 Mar. 2019].

UN Sustainable Development Solutions Network (2013). 2569130918 SDSN Why the World Needs an Urban SDG. [online] Available at: https://sustainabledevelopment.un.org/content/documents/2569130918-SDSN-Why-the-W orld-Needs-an-Urban-SDG.pdf. 
UN-Habitat (2020). Public Space and COVID-19: UN-Habitat. [online] Available at: https://unhabitat.org/sites/default/files/2020/06/final_public_space_key_messages_covid1 9_14_june_2020.pdf [Accessed $10 \mathrm{Jul}$. 2021].

Valsan, S. (n.d.). Livability Quotient a Paradigm Shift in India's Emerging Cities. [online] JLL India. Jones Lang LaSalle Property Consultant (India). Available at: https://www.palava.in/assets/prod/download/pdf/JLL-low.pdf [Accessed 15 May 2021].

Ward, J. (2018). Will Future Megacities Be a Marvel or a Mess? Look at New Delhi. Bloomberg. [online] 3 Nov. Available at: https://www.bloomberg.com/news/features/2018-11-02/india-s-new-delhi-is-example-howurbanization-leads-to-megacities [Accessed 20 May 2021].

World Bank (2019). Urban Development. [online] World Bank. Available at: https://www.worldbank.org/en/topic/urbandevelopment/overview [Accessed 10 Sep. 2020].

World Energy Council: Indian Member Committee (2010). Case Study of Delhi a WEC-IMC Input for Energy for Mega Cities (A WEC Study). [online] Available at: http://indiaenvironmentportal.org.in/files/Delhi\%20case\%20study_APR_22.pdf.

World Health Organization (2010). Urban planning, environment and health From evidence to policy action -Meeting report. [online] Available at: https://www.euro.who.int/_data/assets/pdf_file/0004/114448/E93987.pdf [Accessed 1 Oct. 2020].

World Population Review (2021). Developing Countries 2021. [online] World Population Review. Available at: https://worldpopulationreview.com/country-rankings/developing-countries. 